\title{
Contribution of First Languages Acquisition of Children's Speaking Ability in Assyofa Kindergarten Padang
}

\author{
Rismareni Pransiska \\ Department of Early Childhood Education, \\ Faculty of Education \\ Universitas Negeri Padang \\ pransiskaunp2008@gmail.com
}

\author{
Serli Marlina \\ Department of Early Childhood Education, \\ Faculty of Education \\ Universitas Negeri Padang \\ serlifipunp@gmail.com
}

\begin{abstract}
This study aims to determine the contribution of first language acquisition of children's speaking ability in Assyofa Kindergarten Padang. The type of this research is descriptive correlation. The hypothesis in this study is that there is a significant contribution between the acquisitions of the first language with children's speaking ability. The hypothesis test in this research used product moment formula. From the data analysis conducted there is a significant relationship between the acquisitions of the first language with children's speaking ability in Assyofa kindergarten Padang of 0.412 or $41.2 \%$.
\end{abstract}

Keywords - children; language acquisition; speaking ability

I. Introduction

Language is an important part of everyday life. Through language, someone can communicate and express opinions. When a child is born, he begins to communicate with the world. Language acquisition is a process that takes place in a child's brain when he or she gets his first language or his mother tongue [1] When a child is born, he or she has no language at all, but by the help of time, especially when the child is 4 or 5 years old, he/she has thousands of complex vocabulary, phonology, and grammatical systems that support their communication with the environment.

Based on the initial observation that researchers conducted at Assyofa Kindergarten Padang, on age 4-5 years, children have a very diverse first language type. There are children who have been able to express their feelings and opinions appropriately, who use a variety of vocabulary and they who are able to express the desires and ideas that exist in their thinking. But on the other hand, there are still many who are still reluctant to speak, and embarrassed and did not dare to speak. Sometimes there are also children using language that is not even understood by the teachers. Therefore, researchers were interested in doing research to see whether the process of obtaining the first language made by parents contribute to the children's speaking ability, especially aged 4-5 years.

II. Literature Review

Acquisition of plural language refers to the acquisition of the language of the child. Early children acquire the first language by their interaction with adults in the family environment. Language acquisition is a process of human language development. Normally, the acquisition of the first language is associated with the development of childhood when the acquisition of a second language is based on the development of adult language [2]. Language acquisition takes place automatically or is unnoticed by the child. This is due to children get the language in daily activities that involve interaction with adults around them. Acquisition of the language of children obtained naturally through interaction with the environment [3]

To help the development, parents can help provide stimulation tailored to the uniqueness of every child. There are many stimuli that can be given by parents, especially mothers to her baby. Things that can be done by the mother in giving stimulation to her babies to be able to talk ; (1) communicate with children by using correct word (2) avoid interrupting when the children are talking (3) often invite children to communicate by talking (4) read story with them (5) train children's speech (6) train their speech muscles (7) reward them. Inviting children to communicate with the right words will stimulate them to speak and imitate what we say and what they hear.

\section{Methodology}

In this study the method used is descriptive correlation research that aims to describe and identify the relationship between two or more 
variables. In this research conducted several stages as follows: (1) Preparation of questionnaire; (2) Questionnaire Test; (3) Revision of Questionnaires; (4) Distribution of Questionnaire (5) Data processing. This research was conducted at Assyofa Padang Kindergarten. Assyofa Kindergarten has 48 students; 24 children of Group B1 and 24 children of group B2.

IV. Findings and Discussion

Hypothesis testing in this study used correlation test by the help of SPSS 20. The hypothesis proposed was "the existence of contribution in the acquisition of the first language to the children's speaking ability". From the calculation results it was obtained correlation coefficient $X$ to $Y: \mathbf{0 . 4 1 2}$. The summary of the results of hypothesis analysis can be seen in the following table:

Correlation Analysis of Variables $X$ and $Y$

\begin{tabular}{|l|l|l|}
\hline $\mathrm{R}$ & $\mathrm{r}^{2}$ & Sig \\
\hline 0,412 & 0,170 & 0,010 \\
\hline
\end{tabular}

The results of the calculation in the table above show that the amount of determination of first language acquisition with the children's speaking ability in Assyofa Padang kindergarten is 0.170. The correlation coefficient between first language acquisition and children's speaking ability in Assyofa Padang kindergarten is $\mathbf{0 , 4 1 2}$ with $\rho$ $(\mathrm{sig})=\mathbf{0 , 0 1 0}<\alpha=\mathbf{0 , 0 5}$. This means that there is a significant correlation between first language acquisition and children's speaking ability in Assyofa Padang Kindergarten at $\mathbf{0 . 4 1 2}$ or $\mathbf{4 1 . 2} \%$. From the above description is believed that there is contribution of the acquisition of children's first language to children's speaking ability in Assyofa Padang kindergarten by $\mathbf{0 , 4 1 2}$ or $\mathbf{4 1 , 2} \%$.

Based on the results of data acquisition and data analysis conducted on 38 respondents in Assyofa Padang Kndergarten obtained results that there is a positive correlation and contribution between the acquisition of the child's first language to the children speaking ability. This is indicated by the acceptance of the proposed [4]. From the research he did, it was concluded that the various stimulations performed by parents in children from an early age would greatly affect the development of the language of children in the future. Appropriate stimulation will support the development of pre-school children's language in an optimal way which is not directly affected so that the development of other aspects to the maximum as well.

From some indicators that were proposed to see the children's speaking ability in Assyofa Padang kindergarten it was seen that almost all indicators are distributed equally, so it can be concluded the ability of children talking at Assyofa kindergarten is good enough but there are still variations found. Conditions that cause differences in learning to speak are: (1) health; (2) intelligence; (3) socio-economic situation; (4) sex; (5) the desire to communicate; (6) encouragement; (7) family size; (8) birth order; (9) child training methods; (10) twin births; (11) relationships with peers; (12) personality. Children who become respondents in this study did have differences in intelligence, socioeconomic, and methods of speaking training in children.[5]

V. Conclusion and Suggestion

Based on the above descriptions and findings it can be concluded that parents have an important role to acquire the child's first language. The first language is controlled by the child through interaction with parents and adults around him. Therefore, parents' approach and understanding need to be done so that parents can provide appropriate stimulitions that will create children who are able to communicate effectively.

\section{Acknowledgement}

This work was supported by Department of Early Childhood Education, Faculty of Education, State University of Padang.

\section{References}

[1] Chaer, Abdul. Psikolinguistik Kajian Teoritik. Jakarta: PT. Renika Cipta 2009. P. 167

[2] Guat, Tay Meng. Pemerolehan Bahasa Kanak-kanak: Suatu Analisis Sintaksis. Jurnal Penyelidikan IPBL, Jidil 7, 2006 http://www.ipbl.edu.my/portal/penyelidikan/jurnalpapers/ju rnal2006/tay06.pdf. 2006. P. 2

[3] Habibi, Muazar. 2015. Analisis Kebutuhan Anak Usia Dini. Yogyakarta: Deepublish. 2015. P. 76

[4] Yektiningsih, Erwin. 2010. Hubungan Pemberian Stimulasi Oleh Orang Tua Dengan Perkembangan Bahasa Pada Anak Usia Pra Sekolah (3-5) Tahun di Taman KanakKanak Al Fath Pare. Jurnal AKP No 22010. http://lppm.akperpamenang.ac.id/wpcontent/uploads/2015/05/0201.pdf. 2010. P.2

[5] Hurlock, Elizabeth..Perkembangan Anak. Jakarta : Erlangga. 1998. P. 186 